\title{
CORRIGENDUM
}

\section{Star-Spangled Banner: The Unlikely Story of America's National Anthem. By Marc Ferris. Baltimore, MD: Johns Hopkins University Press, 2014-CORRIGENDUM}

MARIANA WHITMER

doi:10.1017/S1752196317000074. Published by Cambridge University Press, 16 May 2017.

Marc Ferris's name was misspelled in the review of this book titled Star-Spangled Banner: The Unlikely Story of America's National Anthem in the May 2017 issue of Journal of the Society for American Music, both online and in print. It has been corrected online.

\section{Reference}

Whitmer, Mariana. "Star-Spangled Banner: The Unlikely Story of America's National Anthem. By Marc Ferris. Baltimore, MD: Johns Hopkins University Press, 2014." Journal of the Society for American Music 11, No. 2 (May 2017): 215-23. 